\title{
Gebelerde Toxoplazma, Rubella, Sitomegalovirüs Taraması: Yapalım Mı?
}

\author{
Toxoplasma, Rubella, Cytomegalovirus Screening in Pregnant Women: Should We Do It?
}

Deniz KULAKSIZ ${ }^{1}$ Recep ERIN ${ }^{2}$, Yeşim BAYOĞLU TEKINN ${ }^{3}$, Kübra BAKİ ERIN ${ }^{4}$

\section{ÖZ}

Perinatal veya konjenital enfeksiyonlar olarak da adlandırılan Toksoplazma, Rubella, Sitomegalovirüs (TORCH) enfeksiyonları fetüse bulaşarak teratojen etki gösterebilir.

Çalışmadaki amaç, Trabzon ilindeki gebelerde TORCH prevalansını saptamak ve maliyet analizi ile testin gerekliliğini araştırmaktır.

Çalışma retrospektif dosya araştırması şeklinde planlanmıştır. Ocak 2014 ve Aralık 2018 yılları arasında Trabzon Kanuni Eğitim ve Araştırma Hastanesi Kadın Hastalıkları ve Doğum Kliniğinde ayaktan ya da yatarak tedavi almış gebe kadınlar dahil edilmiş̧tir. Dosya taramasından yaş, gravida, parite, VKİ (vücut kitle indeksi), gebelik haftası, fetüs sayısı, özgeçmiş elde edilmiştir. Laboratuvar analizinden TOX IgG/IgM, RV IgG/IgM， CMV IgG/IgM pozitifliği ve avidite verileri elde edilmiştir. Yaş gruplarına göre anlamlılık için ki kare test uygulanmıştır.

Toplam 15985 test yapılmıştır. Anti TOX IgM pozitif olanların yaş ortalaması $27,31 \pm 3,45$, anti rubella IgM pozitif olanların $28,23 \pm 4,53$, anti CMV IgM pozitif olanların ki ise $29,01 \pm 4,76$ idi. Verilerin analizinde gruplar arasinda fark yoktu $(\mathrm{p}>0,05)$. Anti TOX IgG pozitifliği tüm testlerde \%25,9 $(\mathrm{n}=4142)$, anti TOX IgM \%1,53 (n=145), anti TOX IgGM +'lerde düşük avidite \%13,87 (n=34), anti RV IgG \%94,8 ( $\mathrm{n}=15149)$, anti RV IgM \%1 (n=161), anti RV IgGM +'lerde düşük avidite \%14,2 (n=23), anti CMV IgG \%76,1 (n=12163), anti CMV IgM \%1 ( $=165)$, anti CMV IgGM +'lerde düşük avidite \%0,1 $(\mathrm{n}=19)$ bulunmuştur. Toplam test maliyetleri 554329 Türk lirası bulunmuştur.

Sonuç olarak, gebelikte ilk trimesterda anti rubella IgG taranmasını önerilmektedir. Hem maliyet hem de IgGM pozitif çıkanlardaki çok düşük doğrulama testi pozitifliği göz önüne alındığında toxoplazma ve CMV taranmasını önerilmemektedir.

Anahtar kelimeler: Doğu Karadeniz, maliyetetkinlik, TORCH

\section{ABSTRACT}

Toxoplasma, Rubella, Cytomegalovirus (TORCH) infections, also called perinatal or congenital infections, can transmit to the fetus and have a teratogenic effect.

The aim of the study is to determine the prevalence of TORCH in pregnant women in Trabzon and to investigate the necessity of the test with cost analysis.

The study was planned as a retrospective file research. Pregnant women who received outpatient or inpatient treatment at Trabzon Kanuni Training and Research Hospital Gynecology and Obstetrics Clinic between January 2014 and December 2018 were included. Age, gravida, parity, BMI (body mass index), gestational week, number of fetuses, and history were obtained from file scanning. TOX IgG/IgM, RV IgG/IgM, CMV IgG/IgM positivity and avidity data were obtained from laboratory analysis. Chi-square test was applied for significance according to age groups.

A total of 15985 tests were performed. The mean age of those with anti TOX IgM positive was $27.31 \pm 3.45$ years, those with anti rubella $\operatorname{IgM}$ positive were $28.23 \pm 4.53$ years and those with anti CMV IgM positive were $29.01 \pm 4.76$ years. There was no difference between the groups in the analysis of the data $(\mathrm{p}>0.05)$. Anti TOX IgG positivity in all tests $25.9 \%(n=4142)$, anti TOX IgM $1.53 \%(n=145)$, low avidity in anti TOX IgGM + $13.87 \%(\mathrm{n}=34)$, anti RV IgG $94.8 \%(n=15149)$, anti RV IgM 1\% ( $=161)$, low avidity in anti RV IgGM+ $14.2 \%(\mathrm{n}=23)$, anti CMV $\operatorname{IgG} 76.1 \%(\mathrm{n}=12163))$, anti CMV IgM 1\% ( $\mathrm{n}=165)$, low avidity $0.1 \%(n=19)$ in anti CMV IgGM +s. Total test costs were found to be 554329 Turkish liras.

In conclusion, it is recommended to screen for anti rubella $\mathrm{IgG}$ in the first trimester of pregnancy. Considering both the cost and the very low confirmatory test positivity in IgGM positives, screening for toxoplasma and CMV is not recommended.

Keywords: Eastern Black Sea, Cost-effectiveness, TOR

Sağllk Bilimleri Üniversitesi Trabzon Kanuni Sağlık Uygulama ve Araştırma Merkezi’nden idari izin (23618724-772.02) ve Etik Kuruldan 2019/28 numaralı izin alınmıştır.

${ }^{1}$ Dr. Öğr. Üyesi, Deniz KULAKSIZ, Kadın Hastalıkları ve Doğum, SBÜ Trabzon SUAM, drdenizkulaksiz@ gmail.com, ORCID: 0000-0003$2351-1367$

${ }^{2}$ Dr. Öğr. Üyesi, Recep ERIN, Kadın Hastalıkları ve Doğum, SBÜ Trabzon SUAM, erinrecep@gmail.com, ORCID: 0000-0002-9488-5414

${ }^{3}$ Dr. Öğr. Üyesi Kübra BAKİ ERİN, Kadın Hastalıkları ve Doğum, SBÜ Trabzon SUAM, kubrabakierin@ gmail.com, ORCID: 0000-0002-

6626-1735

${ }^{4}$ Prof. .Dr., Yeșim BAYOĞLU TEKİN, Kadın Hastalıkları ve Doğum, SBÜ Trabzon SUAM, yesimbay@ yahoo.com, ORCID: 0000-00030865-3201 


\section{GİRIŞ}

Perinatal veya konjenital enfeksiyonlar olarak da adlandirılan TORCH enfeksiyonlarına, Toxoplasma gondii (TOX), diğer (hepatit virüsleri, parvovirüs, insan immün yetmezlik virüsü, Epstein-Barr virüsü, sifiliz), rubella virüsü (RV), sitomegalovirüs (CMV) ve herpes Simplex virüsü (HSV) neden olmaktadır. ${ }^{1-3}$ Diğer TORCH enfeksiyon grubunda yer alan hepatit virüslerinin, sifilisin ve insan immün yetmezlik virüsünün teşhisi ve yönetimi, açık ve oldukça etkilidir. Bununla birlikte, genellikle asemptomatik ve nispeten düşük virülans olması nedeniyle kolayca gözden kaçan ve teşhis edilmesi zor olan TOX, RV, CMV ve HSV gibi TORCH enfeksiyonlarının çoğu ciddi fetal sonuçlara yol açar. $\mathrm{Bu}$ komplikasyonlar düşükler, intrauterin fetal ölüm ve konjenital malformasyonlar olarak siralanabilir. ${ }^{4}$ TORCH enfeksiyonlarının erken tanınması istenmeyen fetal sonuçlardan kaçınmak, tedavi ve önleme stratejileri için önemlidir.

TOX gondii, kedi dışkısı, kontamine toprak veya az pişmiş et tüketerek yayılan protozoan bir parazittir. ${ }^{3}$ Tropikal bölgelerde en yüksek prevalansla dünya çapında yılda yaklaşı 201000 konjenital toksoplazmoz vakası rapor edilmektedir. Toksoplazmoz, Amerika Birleşik Devletleri'ndeki canlı doğumların 10 ila 33 / 100000'ini etkiler. ${ }^{5}$ Maternal enfeksiyondan sonra fetal enfeksiyon riski, gebeliğin 13. haftasında enfekte ise $\% 15$ 'den 36 . haftada enfekte ise $\% 70$ 'in üzerine çıkar. ${ }^{6}$ TOX'dan şüphelenildiğinde, maternal antikor testi önerilir. IgG en duyarlı testtir çünkü IgM antikorları yüksek bir yanlış pozitif orana sahiptir. Antikor pozitifliğinde avidite testleri yapılmaktadır. Düşük avidite yakın zamanda geçirilmiş bir enfeksiyonu desteklemektedir. ${ }^{7}$

Gebelerde görülen RV enfeksiyonu vakalarında fetal enfeksiyon riskinin \%10-54 arasında olduğu gözlemlenmiştir. Doğuştan Kızamıkçık enfeksiyonları, asemptomatik bulgulardan erken doğum, ölü doğum, katarakt, körlük, sağırlık, mikrosefali ve doğuştan kızamıkçık sendromu olarak bilinen kalp hastalıklarına kadar geniş bir yelpazede yer almaktadir. ${ }^{8,9}$

Konjenital CMV enfeksiyonları genellikle hamilelik sırasında veya gebe kalmadan kısa bir süre önce CMV ile enfekte olduğunda ortaya çıkar. Etkilenen fetüslerde intrauterin büyüme geriliği, polihidramniyoz, perikardiyal ve plevral efüzyon, ventrikülomegali, hidrosefali, intrakraniyal ve plasental kalsifikasyonlar görülebilirken yenidoğanlarda ise mikrosefali, optik atrofi, sensörinöral işitme kaybı, pnömopati ve trombositopeni gibi ciddi sekellere neden olabilir. $^{10,11}$

Türkiye'nin birçok bölgesinden TOX, RV ve CMV enfeksiyon prevalansi bildiren çalışmalar bulunmaktadır. ${ }^{12-14}$ Karadeniz bölgesinde yapılan en geniş prevalans çalışması orta Karadeniz bölgesinde yer alan Tokat ilinde yapılmıştır. $\mathrm{Bu}$ çalışmada seropozitivite oranları Rubella için \%95,4, CMV için \%99,4 ve toksoplazma için \%32 olarak bulunmuştur. ${ }^{15}$ Doğu Karadeniz bölgesinin en büyük ili Trabzon'dur. Literatürde Trabzon ili ile ilgili TORCH prevalans bilgisi bulunmamaktadır.

Uluslarası literatür, TORCH taramasından ilk prenatal vizitte Rubella ve sifilisin taranmas1 önermektedir (Amerikan obstetrisyenler cemiyeti ACOG, 2015). ${ }^{16}$ Ülkemizde ise Kale İ. ve arkadaşları çalışmalarında TOX ve RV taramasını önerirken CMV taraması önermemişlerdir. ${ }^{17}$ Ancak TROCH taraması ilgili fikir birliği hala bulunmamaktadır. Son yıllarda, özellikle gebelikte TORCH testi, giderek daha fazla uygunsuz bir şekilde kullanılmaya başlandı ve bundan dolay1 TORCH testinin endikasyonları ve maliyet etkinliği ile ilgili sorular ortaya çıkt. ${ }^{18-20} \mathrm{Bu}$ nedenle, seropozitiflik oranı ile maliyet analizi birlikte değerlendirilerek testin yapılması ne kadar gerekli onu incelenmesi amaçlanmıştır. 


\section{MATERYAL VE METOT}

\section{Verilerin Toplanması}

Çalışma retrospektif dosya araştırması şeklinde planlanmıştır. Ocak 2014 ve Aralık 2018 yılları arasında Trabzon Kanuni Eğitim ve Araştırma Hastanesi Kadın Hastalıkları ve Doğum Kliniğinde ayaktan ya da yatarak tedavi almış gebe kadınlar dahil edilmiştir. Eksik dosya bilgileri bulunan 116 vaka çalışmaya dahil edilmemiştir. Trabzon'un hatta Doğu Karadeniz Bölgesi'nin tüm kırsal ve kentsel yerleşimlerinden gebeler hastanemize başvurmaktadır. Dosya taramasından yaş, gravida, parite, VKİ (vücut kitle indeksi), gebelik haftası, fetüs sayıs1, özgeçmiş, soygeçmiş bilgisi, doğum şekli, gebeliğe bağlı komplikasyon ve TORCH pozitif olan gebelerde yaşanan komplikasyonlar gibi verilerin elde edilmesi planlanmıştır.

Laboratuvar analizinde TOX $\operatorname{IgG} / \operatorname{IgM}$, RV IgG/IgM ve CMV IgG/IgM pozitifliği olan olgular tespit edilmiş ve kaydedilmiştir. Hastanemiz uygulamasinda TORCH taramasi rutin olmamakla birlikte hekim tercihine göre istek yapılmaktadir. Ancak Klinik uygulamasında IgGM pozitif çıkan gebelere avidite testi hastanemizde rutin yapılmaktadır. Eliza ve avidite testleri için (Abbott Architect, Illionis, USA) kitleri kullanılmıştır. Laboratuvar referans değerleri; TOX IgM:>0,6 IU/ml, TOX IgG:>3IU/ml, TOX avidite >40, RV IgM:>1,6 IU/ml, RV IgG:>4,9 IU/ml, RV avidite: >40, CMV IgM: >1 IU/ml, CMV IgG:>6 IU/ml, CMV avidite: 40 olarak alınmıştır. $^{22}$ Maliyet analizi için Sağlık Bakanlığ1 Halk Sağlığı Genel Müdürlüğü 2020 y1l fiyat tarifeleri ve analiz bilgileri rehberi baz alınarak birim ve toplam test maliyetleri hesaplanmıştır. ${ }^{23}$

İstatiksel analiz için tüm veriler SPSS (version 23.0, Armonk, NY, USA) ortamina aktarılmıştır. Verilerin frekans ve ortalama değerleri hesaplanmıştır. Yıllara ve gruplarına göre anlamlılık için ki kare test uygulanmıştır. $\quad \mathrm{P}<0,05$ anlamlı kabul edilmiştir.

\section{Araştırmanın Etik Yönü}

Sağlı Bilimleri Üniversitesi Trabzon Kanuni Sağlı Uygulama ve Araştırma Merkezi'nden idari izin (23618724-722.02) ve Etik Kurul' dan yerel etik kurul onay1 (2019/28) alınmıştır.

\section{Araştırmanın Kısıtlılıkları}

Çalışmanın önemli bir kisıtlılığ retrospektif olmasıdır. IgM pozitif olanlarda düşük avidite indeksi saptanan gebelerin gebelik kaybının kesin sebebi dosya kayıtlarından anlaşılmamaktadır.

Ayrıca örneklem toplumun tüm fertlerini değil gebe popülasyonu yansitmaktadır. Dosya taramasında eksik, yanlış ya da özensiz dosya bilgileri olan olgular çalışmadan çıkartılmıştır. Hastanemiz, Doğu Karadeniz Bölgesi'nin en büyük ve referans Merkezi olmasına rağmen hastane verileri tüm bölgeyi yansıtmayabilir. Tüm bölgeyi yansitacak veriler için bölgesinin tüm illerinin katıldığı araştırmalarla çalışma desteklenmelidir.

\section{BULGULAR VE TARTIŞMA}

5 y1ll1k verilerin retrospektif analizinde toplam 15985 test yapıldığı tespit edilmiştir. Demografik verilerin analizinde anti TOX IgM pozitif olanların yaş ortalaması $27,31 \pm 3,45$, anti rubella IgM pozitif olanların
$28,23 \pm 4,53$, anti CMV IgM pozitif olanların $\mathrm{ki}$ ise $29,01 \pm 4,76$ bulunmuştur. Grupların demografik verileri Tablo 1'de verilmiştir (Tablo 1). 
Tablo 1. Toxoplazma, Rubella ve CMV (Sitomegalo Virüs) Demografik Verilerin Karşılaştırılması

\begin{tabular}{|c|c|c|c|c|c|}
\hline & & Toxoplasma & Rubella & CMV & $\mathbf{p}$ \\
\hline Yaş & & $27,31 \pm 3,45$ & $28,23 \pm 4,53$ & $29,01 \pm 4,76$ & 0,09 \\
\hline Gravida & & $2,51 \pm 0,34$ & $2,76 \pm 0,65$ & $2,84 \pm 0,21$ & 0,1 \\
\hline Parite & & $2,31 \pm 0,21$ & $2,42 \pm 0,17$ & $2,36 \pm 0,31$ & 0,08 \\
\hline Gebelik haftası & & $8,61 \pm 1,25$ & $9,31 \pm 1,33$ & $9,01 \pm 1,12$ & 0,08 \\
\hline VKI & & $25,65 \pm 4,69$ & $26,21 \pm 4,89$ & $25,87 \pm 5,15$ & 0,07 \\
\hline Ĕgitim düzeyi & İlk öğretim & 18,2 & 19,1 & 17,2 & 0,11 \\
\hline$(\%)$ & Lise & 53,4 & 54,2 & 55,3 & 0,20 \\
\hline & Üniversite & 28,4 & 26,7 & 27,5 & 0,21 \\
\hline Çalışma & Çalışıyor & 21,5 & 23 & 22,7 & 0,23 \\
\hline durumu (\%) & Çalıșmıyor & 78,5 & 77 & 77,3 & 0,16 \\
\hline Maliyet (TL) & & & & & Toplam \\
\hline & Birim maliyet & $6,34 / 202689$ & $5 / 159850$ & $6 / 191820$ & 554329 \\
\hline & Avidite & 24816 & 22506 & 23437 & 1759 \\
\hline & Amniosentez & 321 & 321 & 321 & 3852 \\
\hline & PCR-DNA & 60 & 60 & 60 & 720 \\
\hline & RT-PCR & 195 & 195 & 195 & 585 \\
\hline Genel toplam & & & & & 561.245 \\
\hline
\end{tabular}

CMV: Sitomegalovirüs, TL: Türk lirasl, n:sayl, \%:yüzde

Gruplar arasında yaş, gravida, parite, VKI, gebelik haftası, eğitim düzeyi ve çalışma durumu açısından anlamlı fark bulunmamıştır $(p>0,05)$. Anti TOX IgG pozitifliği tüm testlerde $\% 25,9(n=4142)$, anti TOX IgM 245 (\%1,53), anti RV IgG \%94,8 $(\mathrm{n}=15149)$, anti RV $\operatorname{IgM} \% 1 \quad(\mathrm{n}=161)$, anti CMV IgG \%76,1 ( $\mathrm{n}=12163)$, anti CMV IgM $\% 1 \quad(\mathrm{n}=165)$ bulunmuştur. Gruplarda anti IgM pozitif gelenlere avidite testi yapılmıştır. Aviditenin düşük bulunma oranları TOX, $\mathrm{RV}$, CMV sirasi ile \%0,5 (n=72) / \%0,1 $(\mathrm{n}=23) / \% 0,1 \quad(\mathrm{n}=19)$ bulunmuştur. Avidite düşük bulunanların gebelik kayıp oranları ise sirası ile $n=15 / n=7 n=/ 3$ bulunmuștur. Grup verilerinin y1llara göre değişimi Tablo 2'de verilmiştir (Tablo 2). Y1llara göre enfeksiyon pozitiflik (anti IgM + ) oranları arasında fark bulunmamıştır. Toplam test maliyet oranları TOX, RV, CMV sirasi ile 202689 / 159850 / 191820 Türk lirası bulunmuştur.

Tüm testlerin (TOX, RV, CMV, PCRDNA, RT-PCR, amniosentez) toplam maliyeti ise 561245 Türk liras1 bulunmuştur. $^{23}$

Tablo 2. Yıllara Göre Toksoplazma, Rubella, CMV'ün (Sitomegalo Virüs) IgG, IgM Oranları ve IgM Pozitif Olanlara Yapılan Avidite Testinin Düşük Avidite Pozitiflik Oranları ve Terme Ulaşamayan Gebelik Sayısı

\begin{tabular}{|c|c|c|c|c|c|c|}
\hline Toxoplasma & $\begin{array}{r}2014 \\
(n=2850)\end{array}$ & $\begin{array}{r}2015 \\
(n=2915)\end{array}$ & $\begin{array}{r}2016 \\
(n=3497)\end{array}$ & $\begin{array}{r}2017 \\
(n=3312)\end{array}$ & $\begin{array}{r}2018 \\
(n=3411)\end{array}$ & $\begin{array}{r}\text { Toplam } \\
(\mathrm{n}=\mathbf{1 5 9 8 5})\end{array}$ \\
\hline IgG pozitif, IU/ml & $690(\% 24,2)$ & $\begin{array}{r}715 \\
(\% 24,5)\end{array}$ & $\begin{array}{r}851 \\
(\% 24,3)\end{array}$ & $\begin{array}{r}967 \\
(\% 29,2)\end{array}$ & $919(\% 26,9)$ & $4142(\% 25,9)$ \\
\hline IgM pozitif, IU/ml & $48(\% 1,68)$ & $49(\% 1,68)$ & $47(\% 1,34)$ & $53(\% 1,60)$ & $47(\% 1,37)$ & $245(\% 1,53)$ \\
\hline $\begin{array}{l}\text { IgM +'lerde düşük } \\
\text { avidite }\end{array}$ & $7(\% 6,6)$ & $8(\% 6,2)$ & $9(\% 4,64)$ & $7(\% 7,83)$ & $6(8,54)$ & $34(\% 13,87)$ \\
\hline PCR-DNA & 2 & 1 & 1 & 3 & 3 & 10 \\
\hline Amniosentez & 2 & 2 & 2 & 3 & 3 & 12 \\
\hline $\begin{array}{l}\text { Terme ulaşamayan / } \\
\text { ulaşan gebelik sayısı }\end{array}$ & $2 / 12$ & $3 / 9$ & $3 / 6$ & $3 / 14$ & $4 / 16$ & $15 / 57$ \\
\hline Rubella & $\begin{array}{r}2014 \\
(n=2850)\end{array}$ & $\begin{array}{r}2015 \\
(n=2915)\end{array}$ & $\begin{array}{r}2016 \\
(n=3497)\end{array}$ & $\begin{array}{r}2017 \\
(n=3312)\end{array}$ & $\begin{array}{r}2018 \\
(n=3411)\end{array}$ & $\begin{array}{r}\text { Toplam } \\
(\mathrm{n}=\mathbf{1 5 9 8 5})\end{array}$ \\
\hline IgG pozitif, IU/ml & $2715(\% 95,26)$ & $\begin{array}{r}2835 \\
(\% 97,25)\end{array}$ & $\begin{array}{r}3286 \\
(\% 93,96)\end{array}$ & $\begin{array}{r}3117 \\
(\% 94,1)\end{array}$ & $\begin{array}{r}3196 \\
(\% 94,7)\end{array}$ & $\begin{array}{r}15149 \\
(\% 94,8)\end{array}$ \\
\hline IgM pozitif, IU/ml & $39(\% 1,36)$ & $28(\% 0,96)$ & $31(\% 0,9)$ & $36(\% 1,1)$ & $27(\% 0,8)$ & $161(\% 1)$ \\
\hline
\end{tabular}


Tablo 2. (Devamı) Yıllara Göre Toksoplazma, Rubella, CMV’ün (Sitomegalo Virüs) IgG, IgM Oranları ve IgM Pozitif Olanlara Yapılan Avidite Testinin Düşük Avidite Pozitiflik Oranları ve Terme Ulaşamayan Gebelik Sayısı

\begin{tabular}{|c|c|c|c|c|c|c|}
\hline $\begin{array}{l}\text { IgM +'lerde düşük } \\
\text { avidite }\end{array}$ & $4(\% 10,26)$ & $5(\% 18)$ & $4(\% 12,9)$ & $7(\% 19,4)$ & $3(\% 11,1)$ & $23(\% 14,2)$ \\
\hline Amniosentez & 1 & 2 & 0 & 2 & 0 & 5 \\
\hline RT-PCR & 1 & 1 & 0 & 1 & 0 & 3 \\
\hline $\begin{array}{l}\text { Terme ulaşamayan / } \\
\text { ulaşan gebelik sayısı }\end{array}$ & $0 / 4$ & 14 & $2 / 2$ & $3 / 4$ & $1 / 2$ & $7 / 16$ \\
\hline CMV & $\begin{array}{r}2014 \\
(n=2850)\end{array}$ & $\begin{array}{r}2015 \\
(\mathrm{n}=2915)\end{array}$ & $\begin{array}{r}2016 \\
(n=3497)\end{array}$ & $\begin{array}{r}2017 \\
(n=3312)\end{array}$ & $\begin{array}{r}2018 \\
(n=3411)\end{array}$ & $\begin{array}{r}\text { Toplam } \\
(\mathbf{n}=15985)\end{array}$ \\
\hline IgG pozitif, IU/ml & $2781(\% 97,6)$ & $\begin{array}{r}2796 \\
(\% 95,9)\end{array}$ & $\begin{array}{r}3289 \\
(\% 94,1)\end{array}$ & $\begin{array}{r}3297 \\
(\% 99,5)\end{array}$ & $\begin{array}{r}3213 \\
(\% 94,2)\end{array}$ & $\begin{array}{r}12163 \\
(\% 76,1)\end{array}$ \\
\hline IgM pozitif, IU/ml & $33(\% 1,15)$ & $28(\% 0,96)$ & $34(\% 0,97)$ & $41(\% 1,23)$ & $29(\% 0,85)$ & $165(\% 1)$ \\
\hline $\begin{array}{l}\text { IgM +'lerde düşük } \\
\text { avidite }\end{array}$ & $3(\% 9,1)$ & $3(\% 10,7)$ & $6(\% 17,65)$ & $5(\% 12,2)$ & $2(\% 6,9)$ & $19(\% 0,1)$ \\
\hline Amniosentez & 0 & 0 & 1 & 1 & 0 & 2 \\
\hline PCR-DNA & 0 & 0 & 1 & 1 & 0 & 2 \\
\hline $\begin{array}{l}\text { Terme ulaşamayan / } \\
\text { ulaşan gebelik sayısı }\end{array}$ & $0 / 3$ & $0 / 3$ & $1 / 5$ & $2 / 3$ & $0 / 2$ & $3 / 16$ \\
\hline
\end{tabular}

Türkiye'de yapılan çalışmalarda anti toxoplazma IgG seropozitiflif \%30,3-63 aras1 değişirken TOX IgM ise \%1,3-3,2 arasında bildirilen çalışmalar vardır. ${ }^{13,15,20,7,25}$ Anti toxoplazma IgM pozitif çıkanlara yapılan avidite testinin düşük çıkma oranı ise çalışmalarda \%13,5-29 bildirilmiştir. $^{20,7} \mathrm{Bu}$ çalışmada anti toxoplazma IgM pozitifliğini $245(\% 1,53)$ ve pozitif çıkanlara yapılan avidite testinin düşük olma oranı ise 34 $(\% 13,87)$ saptanmıştır. Avidite testi sonucu düşük çıkan gebelerin amniosentez ve PCRDNA kabul etme oranı $\% 30 \quad(n=22)$ bulunmuştur. Düşük aviditeye sahip gebelerin gebelik kayb1 oranları \%20,8 $(\mathrm{n}=15)$ bulunmuştur. Çalışma sonuçları, Türkiye'deki anti toxoplazma IgM oranları ile benzer bulunmuştur. Yıllara göre TOX IgM pozitifliği dağılıma bakıldığında fark tespit edilmemiştir. IgM pozitif çıkanların sadece \%6-8'inde avidite testi düşük bulunmuştur ( $\mathrm{n}=7 / 48)$. Düşük aviditeye sahip hastaların da çok azı (\%10) ileri aşama testleri (A/S - PCS DNA) yaptırmayı kabul etmiştir. Düşük aviteye sahip olanların gebelik kayb1 oranı yaklaşık \%20'dir $(\mathrm{n}=15 / 57) . \mathrm{Bu}$ oranda genel toplumun spontan abortus $(>\% 20)$ oranına benzerdir. ${ }^{23}$

Maliyet analizi açısından toplam TOX test ücreti (202689 Türk lirası), TOX IgM yanlış pozitiflik oranlarının yüksekliği, gebeliğin hangi döneminde enfeksiyonun geçirileceğinin tahmin edilemeyişi, düşük aviditeye sahip olanların ileri aşama testleri düşük oranda kabul etmeleri ve düşük TOX aviditeye sahip olanlarla normal toplumun gebelik kayıp oranlarının eşitliği göz önüne alındığında toxoplazma seroloji taraması sadece yüksek şüphe duyulan olgularda bak1lmas1 yerinde olacaktır (ACOG 2015). ${ }^{16}$

Nispeten düşük seroprevalans (gebelerin yaklaşık \%38'inin önceden toksoplazmoz enfeksiyonu geçirmiştir) dahil olmak üzere rutin taramayla ilgili birçok zorluk vardır, bu da çoğu kadının enfeksiyona duyarlı olduğu anlamına gelir; nispeten düşük akut enfeksiyon insidans1; referans laboratuarları dışında standartlaştırılmış serolojik testlerin olmaması; ve maliyet düşünüldüğünde toksoplazmoz için hamile kadınların rutin serolojik taramasını önermez. Amerika Birleşik Devletleri'nde toksoplazmoz için doğum öncesi tarama, bağıșıklık sistemi baskılanmış veya insan immün yetmezlik virüsü (HIV) pozitif olan kadınlarla sinırlandırılmaktadır. ${ }^{16,26,27}$

Rubella, enfekte parçacıkların solunması yoluyla yayılan tek sarmallı bir RNA virüsüdür. Dünya çapında rutin aşılama, 2000'den 2014'e kadar vakalarda \%95'lik bir azalmaya yol açarak 2015'te Amerika'dan rubellanın ortadan kaldırıldığı ilan edilmiştir. 
Ülkemizde rubella IgG seropozitiliği \%93-95 arası değişirken, IgM pozitifliği ise \%0,2-0,8 arasıdır. Çalışmada rubella IgM pozitifliği $\% 1$ bulunmuştur. IgM pozitif olanlara yapılan avidite testinde \%14,1 düşük avidite saptanmış ve bunlarında yaklaşık \%50'si ileri testleri yaptırmıştır (RT-PCR, AS). Kesin konjenital rubella tanısı koyulan hastaların yaklaşık yarısının gebeliği düşükle sonuçlanmıştır. Rubella için yapılan testlerin toplam maliyeti 159850 Türk lirasıdır. Mevcut literatür ve çalışma sonuçları 1şığında gebelikte ilk prenatal vizitte rubella $\mathrm{IgG}$ seropozitifliğinin bakılmasını önermekteyiz. TORCH seroprevalansina Suriyeli mültecilerin etkisini inceleyen bir çalışmada tüm TOX, RV ve CMV'nin Suriyeli mültecilerde daha yüksek olduğu bildirilmiştir. Ayrıca aynı çalışmada test maliyeti pozitif çıkan vakalar açısından değerlendirildiğinde taramanın maliyet-etkin olmadı ̆̆ belirtilmiştir. $^{27}$

CMV, canlı doğumların \%2'sini etkileyen en yaygin konjenital viral enfeksiyondur. ${ }^{28}$ Viral bulaşma, idrar, tükürük, servikal ve vajinal sekresyonlar, meni ve anne sütü dahil olmak üzere enfekte sekresyonlarla yakın temas yoluyla gerçekleşir. Amerika Birleşik Devletleri'nde konjenital CMV, çocuklarda uzun vadeli sakatlıkların önde gelen nedenidir ve dünya çapında kalıtsal olmayan işitme kaybının en yaygın nedenidir, etkili tedavi olmadığından rutin test yapılması önerilmez. $^{29} \quad$ Ülkemizde CMV IgG seropozitifliği \%98, IgM seropotifliği ise \%1,6'dır. ${ }^{30}$ Çalışmada gebelerde CMV IgG / IgM seropozitifliği surasi ile \%76 / \%1 bulunmuştur. Test maliyeti 191820 Türk lirasıdır. Serolojik test, viral kültür ve PCR testi ile birlikte en yaygın yöntemdir. Birincil CMV enfeksiyonlarının \%30'undan daha azı, yüksek bir yanlış pozitif oran ile yanlış pozitif IgM gösterecektir; bu nedenle IgG testi 3 ila 4 hafta arayla seri numunelerde gerçekleştirilir.

İngiltere'de üçüncü basamak bir hastanede yapılan bir TORCH çalışmasında 6 yıllık veri analiz edilmiş ve toplam 6000 test yapıldığ ve testlerin en çok istem nedeni olarak polihidramnioz $(\% 20)$ tespit edilmiştir.
Ayrica hangi enfeksiyon etkenini araştırıyorsak onun istenmesine vurgu yapılmış ve bunun ciddi bir maliyete neden olduğu belirtilmiştir. ${ }^{21}$

TORCH testi istem oranı giderek artmaktadır. TORCH testinin artan sayıda kullanım problemleri arasında yanlış endikasyonlar için test talep edilmesinde, tekli serum sonuçlarının yanlış yorumlanmasında ve doğuştan enfeksiyon tanıs1 için iyi bir gösterge olmasına rağmen yanlış test istemi olabilir.

En doğru endikasyon için kullanım konjenital enfeksiyon taraması için kullanımıdır. Klinik endikasyonların doğru koyulması, TORCH testinin en uygun kişiye doğru bir şekilde istenmesi ve çalışılması artan test sayısını azaltabilir ve testin doğru kullanılabilirliğini arttırabilir. Tüm bunlara rağmen TORCH testleri istem sayıs1 artmaktadır. Ayrıca, Klinisyenlerin güncel kılavuzları takip etmemesi ve testin gerekliliğini sorgulamaması nedeniyle test istem sayısında artış olmaktadır. Ülkemiz için tüm toplum bazlı yayınlanmış prevalans çalışması bulunmamaktadır. Mevcut prevalans verileri küçük boyutlu şehir ya da bölge bazında olan çalışmalara dayalıdır. Bakanlığın bu alanda halk sağlığı ile ortak çalışma yürüterek Türkiye geneli ve bölgesel harita çıkarması ve hangi gruba testlerin isteneceği konusunda görüş bildirmesi yerinde olacaktır.

Türkiye'de hemen hemen tüm gebelerden TORCH testi istenmektedir. Bunun sebepleri arasında gebe ve eşinin sosyal medya ve internetten TORCH ile ilgili yeterli ve doğru bilgiyi almadan test talebinde bulunmas1, doktorların herhangi bir gebelik kaybı sonucunda testin istenmediği gerekçesiyle gebe ve eşi tarafından dava edilmesi, sigorta sisteminin geri ödemesinde kisitlama olmaması, hastanın istediği hastaneye istediği zaman başvurabilmesi, hastaneler arası koordinasyonun olmamasından mükerrer test istemi, gebelik takibinin birinci, ikinci ve üçüncü basamak sağlık kuruluşlarının hangisinde takip edileceği ile ilgili tutarsızlıklar sayılabilir. Bütün bunların sonucunda artan test sayısı sigorta sistemine 
ve ekonomiye yük getirmektedir. Tüm nedenlerden ötürü doğru endikasyonlarla

doğru kişiye istenmesi gerekmektedir.

\section{SONUÇ VE ÖNERILER}

Sonuç olarak, TORCH testlerinden gebelikte hatta mümkünse gebelikten önce sadece anti rubella IgG taranmasi önerilmektedir. Bu sayede seronegatif olanlar aşılanabilir. Hem maliyet hem de tıbbi gereklilik açısından gebelikte toxoplazma ve CMV taranması önerilmemektedir. Sadece enfeksiyondan şüphelenildiğinde tetkik edilmesi önerilir.

\section{KAYNAKLAR}

1. Madrid, L, Varo, R, Sitoe, A. and Bassat, Q. (2016) "Congenital and Perinatally-Acquired Infections in ResourceConstrained Settings". Expert Rev Anti-Infect Ther, 14(9), 845-861.

2. Stegmann, B.J. and Carey, J.C. (2002). "TORCH Infections. Toxoplasmosis, Other (Syphilis, Varicella-Zoster, Parvovirus B19), Rubella, Cytomegalovirus (CMV), and Herpes Infections. Curr Womens". Health Rep, 2 (4), 253-258.

3. Neu, N, Duchon, J. and Zachariah, P. (2015). "TORCH Infections". Clin Perinatol, 42 (1), 77-103.

4. Jong, E.P.D, Vossen, A.C.T.M, Walther, F.J. and Lopriore, E. (2013). "How to Use... Neonatal. TORCH Testing". Arch Dis Child Educ Pract Edit, 98 (3), 93-98.

5. Pappas, G, Roussos, N. and Falagas, M.E. (2009) "Toxoplasmosis Snapshots: Global Status of Toxoplasma Gondii Seroprevalence and Implications for Pregnancy and Congenital Toxoplasmosis”. Int J Parasitol, 39, 1385-1394.

6. Thie'baut, R, Leproust, S, Che^ne, G. et al. (2007) "Effectiveness of Prenatal Treatment for Congenital Toxoplasmosis: A Meta-Analysis of Individual Patients' Data". Lancet, 369, 115-122.

7. Bahar, İ.H, Karama, M, Kırdar, S, Yılmaz, Ö, Celiloğlu, M. ve Mutlu, D. (2005). "Gebelikte Toxoplasmosis Tanısında AntiToxoplasma gondii Ig M, IgG, IgA Antikor ve IgG Avidite Testlerinin Birlikteliği ve Önemi”. Türkiye Parazitoloji Dergisi, 29 (2), 76-79.

8. Devakumar, D, Gibson, C.S, Bamford, A, Ferreira, M.U. et al (2018). "Infectious Causes of Microcephaly: Epidemiology, Pathogenesis, Diagnosis, and Management”. Lancet Infect Dis, 18, 1-13.

9. Gibson, C.S, MacLennan, A.H, Goldwater, P.N, Haan, E.A Priest, K and Dekker, G.A. (2006). "South Australian Cerebral Palsy Research Group. Neurotropic Viruses and Cerebral Palsy: Population Based Casecontrol Study". BMJ, 332, 7680.

10. Tastad, K.J, Schleiss, M.R, Lammert, S.M. and Basta, N.E (2019). "Awareness of Congenital Cytomegalovirus and Acceptance of Maternal and Newborn Screening". PLoS One. 14:e221725

11. Ornoy, A. and Diav-Citrin, O. (2006). "Fetal Effects of Primary and Secondary Cytomegalovirus Infection in Pregnancy”. Reprod Toxicoli, 21, 399-409.

12. Yılmazer, M, Altındiş, M, Cevrioğlu, S, Fenkçi, V, Aktepe O. and Sirthan, E. (2004). "Toxoplasma, Cytomegalovirus, Rubella, Hepatitis B and Hepatitis C Seropositivity Rates in Pregnant Women Who Live in Afyon Region". The Medical Journal of Kocatepe, 5, 49-53.

13. Obut, M, Doğan, Y, Bademkıran, M.H, Akgöl, S, Kahveci, B, Peker, N. et al. (2019). "Toxoplasma, Rubella and Cytomegalovirus Seroprevalence in Pregnant Women in Diyarbakir". Dicle Med J, 46 (2), 7.
14. Şentürk, Ş, Kağıtcı, M, Balık, G, Şahin, K. and Şahin, F.K. (2016). "Seroprevalence of Rubella Virus among Pregnant Women in Eastern Black Sea Region". Van Medical Journal, 23 (3), 242-245

15. Çeltek, N.Y, Tetikçok, R, Günal, Ö, Demirtürk, F, Duygu, F, Barut, H.Ş. et al. (2014). "Seroprevalence for Rubella, CMV and Toxoplasmosis among Pregnant Women in Central Black Sea Region of Turkey". Gaziosmanpaşa Üniversitesi Tıp Fakültesi Dergisi, 6 (1), 54-62

16. American College of Obstetricians and Gynecologists. (2015) "Practice bulletin no. 151:Cytomegalovirus, Parvovirus B19, Varicella Zoster, and Toxoplasmosis in Pregnancy". Obstet Gynecol, 125, 1510-1525.

17. Kale, İ, Bayık, R.N, Uluutku, G.B. and Ergin, B. (2020). "Is routine TORCH Screening Necessary for Pregnancy FollowUp?”. Turk J Womens Health Neonatol, 2 (4), 115-121

18. Yamamoto, R, Ishii, K, Shimada, M. et al. (2013) "Significance of Maternal Screening For Toxoplasmosis, Rubella, Cytomegalovirus and Herpes Simplex Virus Infection in Cases of Fetal Growth Restriction". J Obstet Gynaecol Res, 39, 653-657.

19. Chung, M.H, Shin, C.O. and Lee, J. (2018). "TORCH (Toxoplasmosis, Rubella, Cytomegalovirus, and Herpes Simplex Virus) Screening of Small For Gestational Age and Intrauterine Growth Restricted Neonates: Efficacy Study in A Single Institute in Korea”. Korean J Pediatr, 61 (4), 114-120.

20. Çoşkun, B, Gülümser, Ç, Çoşkun, B, Artuk, C. and Karaşahin K.E. (2020). "Impact of Syrian refugees on Congenital TORCH Infections Screening in Turkey". J Obstet Gynaecol, Res 46 (7), 1017-1024.

21. Halawa, S, McDermott, L, Donati, M. and Denbow, M (2014). "TORCH Screening in Pregnancy. Where Are We Now? An Audit of Use in a Tertiary Level Centre". Journal of Obstetrics and Gynaecology, 34, 309-312.

22. Villard, O, Breit, L, Cimon, B. et al. (2013). "French Nationa Reference Center for Toxoplasmosis Network. Comparison of Four Commercially Available Avidity Tests for Toxoplasma Gondii-Specific IgG Antibodies". Clin Vaccine Immunol, 20 (2), 197-204.

23. T.C. Sağlık Bakanlığı Halk Sağlığı Genel Müdürlüğü. (2020) Ankara: 2020 Yılı Fiyat Tarifeleri ve Analiz Bilgileri Rehberi.

24. Nazik, S, Duran İ, Nazik, H. and Duran, Ş. (2017) "Evaluation of Toxoplasma and Rubella Seropositivity in Pregnancy”. Balıkesir Medical Journal ,1(1), 22-25.

25. Bakacak, M, Bostancı, S.M, Köstü, B, Ercan, Ö, Avcı, S.F and Bakacak Z. (2014). "Seroprevalance of Toxoplasma Gondii, Rubella And Cytomegalovirus among Pregnant Women”. Dicle Medical Journal, 41 (2), 326-331.

26. Craig, P.G, Halvorsen, J, Golemon, T.B. and Anthony, A.D (2005). "Management of Spontaneous Abortion". Am Fam Physician, 72(7), 1243-1250. 
27. Leeper, C. and Lutzkanin, A. (2018). "Infections During Pregnancy". Prim Care, 45 (3), 567-586.

28. Staras, S.A.S, Flanders, W.D, Dollard, S.C, et al. (2008). "Cytomegalovirus Seroprevalence and Childhood Sources of Infection: a Population-Based Study among Preadolescents in the United States". J Clin Virol, 43, 266-271.

29. Silasi, M, Cardenas, I, Racicot, K, Kwon, J, Aldo, P. and Gil, M. (2015). "Viral Infections during Pregnancy". Am J Reprod Immunol, 73 (3), 199-213.

30. İnci, A, Yener, C. and Güven, D. (2014). "The Investigation of Toxoplasma, Rubella and Cytomegalovirus Seroprevalancies in Pregnant Women in A State Hospital". Pam Tip Derg, 7 (2), 143-146. 